\title{
Vaccine against Dental Caries: An Update
}

\author{
Diego Romário da Silva1, Andréa Cristina Barbosa da Silva1*, Robeci Macedo Filho1, \\ Flaviana Dornela Verli ${ }^{2}$, Sandra Aparecida Marinho ${ }^{1}$ \\ ${ }^{1}$ Graduate Program in Dentistry, Center of Sciences, Technology and Health, State University of Paraiba, \\ UEPB, Araruna, Paraíba, Brazil \\ ${ }^{2}$ Department of Biological Sciences, Federal University of the Jequitinhonha and Mucuri Valleys, UFVJM, \\ Diamantina, Minas Gerais, Brazil \\ Email: ${ }^{*}$ andreacbsilva@gmail.com
}

Received 14 August 2014; revised 12 September 2014; accepted 8 October 2014

Copyright (C) 2014 by authors and Scientific Research Publishing Inc.

This work is licensed under the Creative Commons Attribution International License (CC BY).

http://creativecommons.org/licenses/by/4.0/

(c) (i) Open Access

\begin{abstract}
Dental caries, the disease that causes tooth decay, is infectious, and the mutans streptococci bacteria have long been identified as the primary disease-causing agents. Caries vaccines showed promising results in experimental studies; however, it remains far the effective use in humans due to political-economic and ethical issues. Progress towards practical vaccine development requires evaluation of candidate vaccines in clinical trials. Promising strategies of passive immunization also require further clinical evaluation. The purpose of this chapter is to review the literature on the main research projects aimed at developing caries vaccines.
\end{abstract}

\section{Keywords}

Caries, Vaccine, Immunology

\section{Introduction}

Dental caries is a multifactorial infectious disease, dependant on diet, oral microbiota and host response, and resulting on the demineralization located in the hard dental tissues [1]. Streptococcus mutans, a Gram positive, aciduric and acidogenic bacteria, is considered a microorganism more associated to this pathology [2]. Dental biofilm, in which S. mutans is inserted, is a community of bacteria attached to salivary components and embedded in a matrix of glucan of high molecular weight, produced by this microorganism [3].

Advances in molecular biology have facilitated the cloning and the functional characterization of virulence factors of mutans streptococci. The glucan polymer matrix produced by this microorganism, as well as the antigens (Ags) of virulence found on its surface, is considered mainly responsible for their biofilm-forming ability

"Corresponding author. 
and are thus important for their adhesion and accumulation in the biofilm [4].

In search of new preventive measures against caries, in addition to the consolidated ones, as the disorganization of the biofilm by brushing and using toothpaste with or without fluoride [5] [6], some researches have been conducted with the aim of developing a caries vaccine [7]-[11].

Thus, the purpose of this article was to conduct a brief review of the literature on the prospects for caries control by means of a vaccine, which would be able to inhibit or attenuate the virulence factors of $S$. mutans in biofilm.

\section{Literature Review}

The biofilm is a cluster of bacteria dispersed in a matrix of extracellular polymers (polysaccharides, proteins), DNA and other metabolites. One of the main virulence characteristics of S. mutans is its ability to produce glycosyltransferases (Gtfs), enzymes that synthesize intracellular polysaccharides (ICP) and extracellular polysaccharides (ECP) from the diet's sucrose. The glucans, polysaccharides synthesized by the Gtfs of the streptococci, provide attachment of sites microorganisms within dental surfaces, starting a biofilm formation and aggregation of $S$. mutans to other oral streptococci [3].

Several measures are being used in the prevention and control of caries, as the disorganization of the biofilm through oral hygiene and use of fluorides [12]. However, the still high prevalence of such disease in the world population [13], justifies the search for a new preventive action, such as the development of a caries vaccine. The main target is the mechanism of adherence of $S$. mutans, which can be affected by active or passive immunization [14] [15], or by DNA vaccines [9]-[11].

Three main groups of Ags associated with the surface of $S$. mutans participate in the adherence and accumulation of this biofilm: the GTFS, the adhesin antigen I/II (Ag I/II) and the glucan binding proteins (GBP), considered the main targets for the development of a caries vaccine [8].

Dental caries involves the interaction between the bacterial attack and host defense and may be modulated by the interference of these factors [16]. The innate immune defense of the host alone appears to be ineffective in an effective anticaries protection. As for the components of the acquired immunity (adaptive) present a more significant role, highlighting the Salivary Immunoglobulin A (SIgA) generated by the mucosal immune system, being actively secreted by plasma cells of the glandular stroma itself, present in saliva. Immunoglobulins $G$ and M (IgG and IgM) are also involved in the defense against dental caries, to a lesser extent [17] [18]. Furthermore, the groove crevicular also contains various cellular components of the immune system such as lymphocytes, macrophages and neutrophils [19].

Passive immunization consists of the topical application of antibodies (Abs) performed antigen-specific on the surface of teeth against the virulence factors of $S$. mutans. As for the active immunization, it involves the application of microbial antigens (Ags), inducing the mucosal immune system, by stimulating the production of specific SIgA; besides induction of the systemic immune system, stimulating the production of serum Abs [7], which may be used in DNA vaccines [9]-[11]. The main immunological studies for developing a caries vaccine are based on active immunization [7].

Since it does not provoke a stimulation of the host immune system and therefore does not generate a response of immune memory, passive immunization is considered less effective than the active [20], thus, repeated applications of vaccines are required, since the action is purely local. For not presenting adverse effects, this type of vaccine has been tested in humans. Ma et al. (Ma et al., 1990) [20], performed a local passive immunization with oral administration of the antibody (Ab) monoclonal specific to S. mutans (MAb) in humans. The authors found that the Ab prevented the recolonization of the biofilm on the tooth surface; however, the individuals had previously performed mouthwash with chlorhexidine, a potent antimicrobial. Thus, the tested Ab prevented a new formation of biofilm, however, it may not have significant efficacy in old biofilm, not previously treated with chlorhexidine. Yet, since those Abs remain in saliva only for a few hours, it is difficult to maintain a sufficiently adequate level of $\mathrm{Ab}$ in the biofilm in order to take effective action.

Active induction of the immune system is aimed at incorporating Ags purified from S. mutans in the mucosal immune systems [21] [22] and by blocking the surface receptor of the modification of bacterial enzymes metabolic functions, Abs would be able to significantly reduce biofilm formation and, consequently, the development of caries [23].

Active immunization by direct topical application of Ag in the oral cavity stimulates the production of specific SIgA in saliva while the application of Ag via intramuscular or subcutaneous route only induces the production of serum Abs (IgM and IgG), which would only reach the tooth surface through the gingival crevicular fluid. 
The SIgA prevents adhesion of microorganisms to the surface of the tooth, preventing the beginning of bacterial colonization [7] [22] [23].

Some experiments were performed with Ag purified peptide, obtained from the regions amino and carboxylterminal domain with Gtfs of $S$. mutans, for active immunization of rats. An increase of specific IgG serum for Gtfs and a consequent significant reduction in caries infected with S. mutans and S. sobrinus [24] was observed. Both rats and monkeys immunized with the amino terminal portion, which has binding region with saliva, exhibited significantly less activity in caries when compared to animals immunized with the carboxy-terminal portion, which has no connection to the saliva [25]-[27].

The most used animal models for anticaries vaccine tests are rodents, mostly mice and rats [10] [28] [29]. Despite the success in rodents [30], these results cannot be extrapolated to humans because of the short time of caries development in these animals [8] [24], besides the fact that S. sobrinus has greater cariogenic potential in these animals than S. mutans, unlike humans [31] [32]. Also, rats and mice have dental morphology and caries' standards different from humans. As for humans, the actual contribution of $S$. sobrinus in their caries remains uncertain. For these reasons, researches have been conducted in primates, whose immune conditions, etiologic agent and duration of biofilm formation are similar to what occurs in humans, with a bacterial colonization standard in occlusal pits and fissures and proximal sites, similar to humans [16]. However, for being large animals, the experimental groups tend to be smaller, running into ethical issues, making it a more costly and relatively impractical experiment.

Despite the relative success of research with rodents and primates [10] [33], there may still be a cross-reactivity between surface Ags and S. mutans of human cardiac tissue [34] [35]. According to Zhang et al. [36], the development of caries vaccine requires that the immunogen is extremely effective and causes no side effect, which does not occur with the formulations of vaccine currently tested.

The genetic sequences of certain oral microorganisms, such as the $S$. mutans UA159 [37], made it possible to know the most important parts of the main Ags, which can induce a better immune response. Molecular genetic techniques have been applied in the construction of hybrid molecules for this purpose [36] [38]. Thus, new ways of presenting these immunogenes have been developed, including DNA vaccine, which is obtained by transfection and subsequent production of a specific protein for immunization [9]. The DNA of $S$. mutans, used for the development of this type of vaccine is extracted by mechanical or chemical lysis and, in its genetic material, we find the gene encoding the antigenic protein, which will be used for immunization [39].

Generally, for the development of a genetic anticaries vaccine, the catalytic region (CAT) and the glucans binding domain (GBD) of the glucosyltransferase B (GtfB) of Streptococcus mutans have been used as Ags. These regions have been selected because, in theory, they include epitopes associated with its enzymatic function. [40] found that the variable region (VR) at the N-terminal of GtfB is specific to S. mutans and is not conserved among other streptococcal Gtfs, being a promising epitope for the development of an effective vaccine.

The DNA vaccine is safer and more stable due to its method of application and storage; easy preparation and administration, and ability to induce effective immune response while stimulating $\mathrm{T}$ and $\mathrm{B}$ lymphocytes. It also presents great potential for further modification and improvement [41]. However, the need for large amounts availability (milligrams or grams) of this vaccine to make it effective prevents it from being conventionally produced in laboratory, requiring large-scale industrial production [11].

DNA vaccines associated with mucosal adjuvants, like heat-labile enterotoxins of Vibrio cholerae and Escherichia coli aggregated to chitosan and bupivacaine have been successful in animal models. However, these vaccines are still not effective due to their poor capacity to induce and maintain the oral fluid antibodies [42] [43] [29].

Some important studies are summarized in Table 1.

Other approaches such as the use of certain small peptides corresponding to binding regions of streptococcal adhesin, including receptors of carbohydrates, have been used as a means of preventing the adhesion of specific microorganisms [47]-[49]. However, it is necessary to achieve a minimum concentration of these peptides in order to compete with the biofilm bacteria [16].

\section{Final Remarks}

Despite the promising laboratory advances, anticaries vaccines are still far from being a current reality, since most studies are done in small animals, making it difficult to extrapolate to humans. Despite the large number of 
Table 1. Relevant studies published on anticaries vaccine.

\begin{tabular}{|c|c|c|c|c|c|c|}
\hline $\begin{array}{c}\text { Author } \\
\text { and Year }\end{array}$ & $\begin{array}{l}\text { Type of } \\
\text { study } \\
\text { (in vitro or } \\
\text { in vivo) }\end{array}$ & $\begin{array}{c}\text { Type of } \\
\text { vaccine (DNA or } \\
\text { protein-antibody) }\end{array}$ & $\begin{array}{l}\text { Type of animal } \\
\text { (in vivo studies) } \\
\text { and type of cell }\end{array}$ & $\begin{array}{c}\text { Route of } \\
\text { administration } \\
\text { (in vivo } \\
\text { studies) }\end{array}$ & Results & Conclusion \\
\hline $\begin{array}{l}\text { [11] } \\
\text { Yang et al., } \\
2009 .\end{array}$ & In vivo & $\begin{array}{l}\text { Vaccine DNA } \\
\text { pGJA-P/VAX }\end{array}$ & $\begin{array}{l}\text { Gnotobiotic mice } \\
\text { and rats }\end{array}$ & Intranasal & $\begin{array}{l}\text { Increased production of } \\
\text { IgG and SIgA. } \\
\text { Decreased growth of } \\
\text { caries lesions in enamel, } \\
\text { dentin light lesions and } \\
\text { dentin moderate lesions } \\
\text { of } 21.1 \% \text {, } 33.0 \% \text { and } \\
40.9 \% \text {, respectively. }\end{array}$ & $\begin{array}{l}\text { The production } \\
\text { process of pGJA-P/ } \\
\text { VAX preparation } \\
\text { was efficient. The } \\
\text { vaccine showed a } \\
\text { high degree of } \\
\text { purity and desired } \\
\text { efficiency, thereby } \\
\text { facilitating future } \\
\text { clinical trials of } \\
\text { this anticaries } \\
\text { DNA vaccine. }\end{array}$ \\
\hline $\begin{array}{c}\text { [10] } \\
\text { Zhang } \\
\text { et al., } 2007 .\end{array}$ & $\begin{array}{l}\text { In vivo/in } \\
\text { vitro }\end{array}$ & $\begin{array}{l}\text { Vaccine DNA } \\
\text { pGJA-P/VAX1 } \\
\text { pGJA-P } \\
\text { pGLUA-P }\end{array}$ & $\begin{array}{l}\text { Gnotobiotic } \\
\text { hamster/human } \\
\text { dendritic cells }\end{array}$ & $\begin{array}{c}\text { Intramuscular/ } \\
\text { intranasal }\end{array}$ & $\begin{array}{l}\text { Vaccines pGJA-P/vax1 } \\
\text { and pGJA-P induced } \\
\text { higher response of } \\
\text { salivary and serum } \\
\text { antibodies than } \\
\text { pGLUA-P. Fewer } \\
\text { caries lesions were } \\
\text { observed in hamsters } \\
\text { immunized with } \\
\text { pGJA-P/vax1 and } \\
\text { pGJA-P. }\end{array}$ & $\begin{array}{l}\text { The antigen } \\
\text { encoded by } \\
\text { CTLA-4 associated } \\
\text { to DNA vaccine } \\
\text { pGJA-P/vax1 can } \\
\text { bind specifically to } \\
\text { human dendritic } \\
\text { cells. Furthermore, } \\
\text { this combination } \\
\text { increased the } \\
\text { immunogenicity and } \\
\text { protective efficacy } \\
\text { of the vaccine. }\end{array}$ \\
\hline $\begin{array}{l}\text { [9] } \\
\text { Xu et al., } \\
2005 .\end{array}$ & In vivo & $\begin{array}{l}\text { Vaccine DNA } \\
\text { pGJA-P/VAX }\end{array}$ & Mice & Intranasal & $\begin{array}{l}\text { Antibody responses } \\
\text { induced by pGJA-P/ } \\
\text { VAX lasting more than } 6 \\
\text { months. Furthermore, the } \\
\text { pGJA-P/VAX could still } \\
\text { be detected either at the } \\
\text { site of inoculation, and in } \\
\text { the cervical lymph nodes } \\
\text { draining, } 6 \text { months after } \\
\text { immunization. }\end{array}$ & $\begin{array}{l}\text { The persistent } \\
\text { immune responses } \\
\text { are probably due } \\
\text { to the deposit of } \\
\text { DNA into the host, } \\
\text { which acts as a } \\
\text { booster } \\
\text { immunization. Thus, } \\
\text { there is a greater } \\
\text { immunological } \\
\text { memory. }\end{array}$ \\
\hline $\begin{array}{l}{[29]} \\
\text { Xu et al., } \\
2007 .\end{array}$ & In vivo & $\begin{array}{l}\text { Vaccine DNA } \\
\text { pGJA-P/VAX }\end{array}$ & Rats & Intranasal & $\begin{array}{l}\text { SIgA response were } \\
\text { induced, resulting in } \\
\text { reduction of enamel and } \\
\text { dentin lesions caused by } \\
\text { S. mutans and reduced } \\
\text { enamel lesions in } \\
\text { individuals infected with } \\
\text { S. sobrinus }\end{array}$ & $\begin{array}{l}\text { pGJA-P/VAX } \\
\text { induces immune } \\
\text { response only to } \\
\text { infection by } S \text {. } \\
\text { mutans, but also } \\
\text { provided } \\
\text { cross-protection } \\
\text { against } S \text {. sobrinus } \\
\text { strain infection in } \\
\text { rats. }\end{array}$ \\
\hline $\begin{array}{c}{[24]} \\
\text { Talbman } \\
\text { et al., } 1995 .\end{array}$ & In vivo & $\begin{array}{c}\text { CAT or GLU } \\
\text { (specific region of } \\
\text { Gtf de } S \text {. mutans) }\end{array}$ & Rats & $\begin{array}{l}\text { Infection with } \\
\text { the regions } \\
\text { of GTF. }\end{array}$ & $\begin{array}{l}\text { Increased of specific } \\
\text { serum IgG for Gtf; } \\
\text { Significant reduction of } \\
\text { caries. }\end{array}$ & $\begin{array}{l}\text { Immunization with } \\
\text { peptides derived } \\
\text { from functional } \\
\text { domains of } S \text {. } \\
\text { mutans Gtf are } \\
\text { protective for } \\
\text { infection with } \\
\text { S. sobrinus or } \\
\text { S. mutans. }\end{array}$ \\
\hline
\end{tabular}




\section{Continued}

\section{[30] \\ Mitoma}

et al., 2002

In vivo

Antibodies

Rats

Topic

[33]

Russell e

Colman,

1981.

[27] Lehner et al., 1981.

In vivo

Protein

(Antigens I, II e III)

Monkeys

Orally

[42] Jia et al., 2006.

In vivo

Vaccine of DNA pGJA-P/VAX

Rabbits and monkeys

Intranasal/ (milk immune) Intramuscular
The group of rats receiving milk with antibodies had significantly less caries development than the control group.
Immunization showed decrease in caries development in rats and may present similar results in humans. However, the duration is uncertain and because it is a passive immunization does not generate a lasting response.

Immunized monkeys showed elevated levels of serum antibodies against Gtf, but there was no difference in the development of dental caries among immunized animals and the control group.

There was no reduction of caries in monkeys immunized with antigen III. The reduction of caries in the immunized animals with antigens I or I/II was discrete.

The antigens vaccine fused to cytotoxic $\mathrm{T}$ lymphocytes induced increase in specific antibody responses in serum and in saliva compared to DNA vaccine without fusion, in rabbits. Significant levels of IgG in specific serum and salivary IgA were also detected in monkeys immunized with fusion vaccine.

Intramuscular/

Lower levels of caries

Fan et al., In vivo Vaccine of DNA pCIA-P
Gnotobiotic rats
The Gtf showed no ability to induce specific immune response against cariogenic pathogens.

The protection against caries was associated predominantly to IgG antibodies of gingival fluid, driven, possibly to antigen I.

The fusion of the CTLA4 antigen results in improved immunological efficacy and strongly suggests that it may represent a promising approach to prevent dental caries and other infectious diseases.

The DNA vaccine pCIA-P recombinant can induce anticaries protection and immune responses through the injection salivary gland are a promising strategy for inhibiting dental caries. submucosa/

sub-cutaneous (salivary gland) and high levels of serum sIgA and IgG after direct application in salivary gland were observed. 


\section{Continued}

$\begin{array}{cccc}{[44]} & \text { Vaccine of DNA } & \text { Gnotobiotic rats } & \begin{array}{c}\text { Intramuscular/ } \\ \text { intranasal }\end{array} \\ \text { Niu } \text { et al., } & \text { In vivo } & \text { pGJA-P/VAX }\end{array}$

[45]

Chen et al., In vitro

2013.
pGJA-P/VAX
Vaccine DNA
Vaccine was successful in the reduction of levels of caries caused by $S$. mutans in gnotobiotic animals. However, its protecting effect against the infection by $S$. sobrinus proved to be weak.

In comparison with the system of Chitosan/ traditional DNA, the new design has yielded higher transfection efficiency and increased residence time of anionic lipsome/Chitosan/DNA, which will induce a higher level of sIgA on "in vivo" study.

Mice immunized with the variation pCI-IL-6 showed less decay than the control group
After cloning the catalytic region (cat) of the Gtf-I fragment of $S$. sobrinus, a synthesis inhibition of the insoluble glucan in water by $S$. sobrinus, which can result in a new variation of pGJA-P/VAX to produce an anticaries DNA vaccine.

While this new complex appears to have minimal toxicity, the results suggest that the developed nanoparticles have a "delivery" potential of DNA vaccines, which will make mucosal immunity more efficient.

Intranasal co-administration of IL-6 significantly improves the immunogenicity of the anticaries DNA vaccine.

laboratory studies with experimental animals and the evidence of vaccines' efficacy, there is no marketability for human use [46]. The vaccine production requires large-scale investments, largely burdening their cost, which is not feasible and advantageous for public health systems. In addition, some challenges must be overcome through further research, as the residence time of the vaccine with appropriate concentration in the oral cavity, best route of administration, as well as a reduction in the possibility of cross-reactions [50]. Still, it should be pointed out that dental caries is a multifactorial disease, which can be prevented and controlled by other simple means and with lower costs, such as proper hygiene and use of fluorides, which are already established in the literature.

\section{References}

[1] Keyes, P.H. (1960) The Infectious and Transmissible Nature of Experimental Dental Caries. Archives of Oral Biology, 1, 304-320. http://dx.doi.org/10.1016/0003-9969(60)90091-1

[2] Loesche, W.J. (1986) Role of Streptococcus mutans in Human Dental Decay. Microbiology Reviews, 50, 353-380.

[3] Marsh, P.D and Bradshaw, D.J. (1995) Dental Plaque as a Biofilm. Journal of Industrial Microbiology, 15, 169-175. http://dx.doi.org/10.1007/BF01569822

[4] Bowen, W.H and Koo, H. (2011) Biology of Streptococcus mutans Derived Glucosyltransferases: Role in Extracellular Matrix Formation of Cariogenic Biofilms. Caries Research, 45, 69-86. http://dx.doi.org/10.1159/000324598

[5] Featherstone, J.D.B. (2000) The Science and Practice of Caries Prevention. The Journal of the American Dental Association, 131, 887-899. http://dx.doi.org/10.14219/jada.archive.2000.0307

[6] Balakrishman, M., Simmonds, R.S and Tagg, J.R. (2000) Dental Caries Is a Preventable Infectious Disease. Australian 
Dental Journal, Sydney, 45, 235-245. http://dx.doi.org/10.1111/j.1834-7819.2000.tb00257.x

[7] Michalek, S.M and Childers, N.K. (1990) Developmental and Outlook for Caries Vaccine. Critical Reviews in Oral Biology and Medicine, Alexandria, 1, 37-54.

[8] Russel, M.W., Childers, N.K., Michalek, S.M., Smith, D.J. and Taubman, M.A. (2004) A Caries Vaccine? The State of the Science of Immunization against Dental Caries. Caries Research, 38, 230-235.

[9] Xu, Q.A., Yu, F., Fan, M., Bian, Z., Guo, J., Jia, R., Chen, Z., Peng, B and Fan, B. (2005) Immunogenicity and Protective efficacy of Targeted Fusion DNA Construct against Dental Caries. Caries Research, 39, 422-421. http://dx.doi.org/10.1159/000086851

[10] Zhang, F., Li, Y.H., Fan, M.W., Jia, R., Xu, K.A., Guo, J.H., Yu, F. and Tian, K.W. (2007) Enhanced Efficacy of CTLA-4 Fusion Anticaries DNA Vaccines in Gnotobiotic Hamsters. Acta Pharmacologica Sinica, 28, 1236-1242. http://dx.doi.org/10.1111/j.1745-7254.2007.00600.x

[11] Yang, Y.P., Li, Y.H., Bi, L. and Fan, M.W. (2009) Good Manufacturing Practices Production and Analysis of DNA Vaccine against Dental Caries. Acta Pharmacologica Sinica, 30, 1513-1521. http://dx.doi.org/10.1038/aps.2009.152

[12] Featherstone, J.D.B. (1999) Prevention and Reversal of Dental Caries: Role of Low Level Fluoride. Community Dentistry and Oral Epidemiology, 27, 31-40. http://dx.doi.org/10.1111/j.1600-0528.1999.tb01989.x

[13] Bagramian, R.A., Garcia-Godoy, F. and Volpe, A. (2009) The Global Increase in Dental Caries. A Pending Public Health Crisis. American Journal of Dentistry, 22, 3-8.

[14] Levine, M., Owen, W.L. and Avery, K.T. (2005) Antibody Response to Actinomyces Antigen and Dental Caries Experience: Implications for Caries Susceptibility. Clinical and Diagnostic Laboratory Immunology, 12, 764-769.

[15] Robinette, R.A., Oli, M.W., Mcarthur, W.P. and Brady, L.J. (2011) A Therapeutic Anti-Streptococcus mutans Monoclonal Antibody Used in Human Passive Protection Trials Influences the Adaptive Immune Response. Vaccine, 29, 6292-6300. http://dx.doi.org/10.1016/j.vaccine.2011.06.027

[16] Russel, R.R.B. (2011) Pode o controle da cárie envolver imunização e terapia genética? In: Fejerskov, O. and Kidd, E., Eds., Cárie Dentária: A doença e seu tratamento Clínico, 2a Edição, Editora Santos, São Paulo, 640.

[17] Morrier, J.J. and Barsoti, O. (1990) Secretory IgA and the Oral Cavity: General Review. Actualites OdontoStomatologiques, 44, 349-363.

[18] Hofling, J.F. and Gonçalves, R.B. (2006) Imunologia para odontologia. Editora Artmed, Porto Alegre, 310.

[19] Shivakumar, K.M., Vidya, S.K. and Chandu, G.N. (2009) Dental Caries Vaccine. Indian Journal of Dental Research, 20, 99-106. http://dx.doi.org/10.4103/0970-9290.49066

[20] Ma, J.K.C., Hunjan, M., Smith, R., Kelly, C. and Lehner, T. (1990) An Investigation into the Mechanism of Protection by Local Passive Immunization with Monoclonal Antibodies against Streptococcus mutans. Infection and Immunity, 58, 3407-3414.

[21] Oli, M.W., Rhodin, N., Mcarthur, W.P. and Brady, L.J. (2004) Redirecting the Humoral Immune Response against Streptococcus mutans Antigen p1 with Monoclonal Antibodies. Infection and Immunity, 72, 6951-6960. http://dx.doi.org/10.1128/IAI.72.12.6951-6960.2004

[22] Nogueira, R.D., Alves, A.C., Napimoga, M.H., Smith, D.J. and Mattos-Graner, R.O. (2005) Characterization of Salivary Immunoglobulin a Responses in Children Heavily Exposed to the Oral Bacterium Streptococcus mutans: Influence of Specific Antigen Recognition in Infection. Infection and Immunity, 73, 5675-5684. http://dx.doi.org/10.1128/IAI.73.9.5675-5684.2005

[23] Chen, F. and Wang, D. (2010) Novel Technologies for the Prevention and Treatment of Dental. Expert Opinion on Therapeutic Patents, 20, 681-694. http://dx.doi.org/10.1517/13543771003720491

[24] Taubman, M.A., Holmberg, C.J. and Smith, D.J. (1995) Immunization of Rats with Synthetic Peptide Constructs from the Glucan Biding or Catalytic Region of Mutans. Infection and Immunity, 63, 3088-3093.

[25] Russel, M.W., Hajishengallis, G., Childers, N.K. and Michalek, S.M. (1999) Secretory Immunity in Defense against Cariogenic Mutans Streptococci. Caries Research, 33, 4-15. http://dx.doi.org/10.1159/000016490

[26] Hajishengallis, G. and Michalek, S.M. (1998) Current Status of a Mucosal Vaccine against Dental Caries. Oral Microbiology and Immunology, 13, 326-345.

[27] Lehner, T., Russell, M.W., Caldwell, J. and Smith, R. (1981) Immunization with Purified protein Antigens from Streptococcus mutans against Dental Caries in Rhesus Monkeys. Infection and Immunity, 34, 407-415.

[28] Xu, Q.A., Yu, F., Fan, M.W., Bian, Z., Chen, Z., Fan, B., Jia, R. and Guo, J.H. (2006) Immunogenicity and Persistence of a Targeted Anti-Caries DNA Vaccine. Journal of Dental Research, 85, 915-918. http://dx.doi.org/10.1177/154405910608501008

[29] Xu, Q.A., Yu, F., Fan, M.W., Bian, Z., Chen, Z., Peng, B., Jia, R. and Guo, J.H. (2007) Protective Efficacy of a Tar- 
geted Anti-Caries DNA Plasmid against Cariogenic Bacteria Infections. Vaccine, 25, 1191-1195. http://dx.doi.org/10.1016/j.vaccine.2006.10.013

[30] Mitoma, M., Oho, T., Michibata, N., Okano, K., Nakano, Y., Fukuyama, M. and Koga, T. (2002) Passive Immunization with Bovine Milk Containing Antibodies to a Cell Surface Protein Antigen-Glucosyltransferase Fusion Protein Protects Rats against Dental Caries. Infection and Immunity, 70, 2721-2724. http://dx.doi.org/10.1128/IAI.70.5.2721-2724.2002

[31] Ooshima, T., Sobue, S., Hamada, S. and Kotani, S. (1981) Susceptibility of Rats, Hamsters, and Mice to Carious Infection by Streptococcus mutans Serotype c and d Organisms. Journal of Dental Research, 60, 855-859. http://dx.doi.org/10.1177/00220345810600041701

[32] Soet, J.J., Van loveren, C., Lammens, A.J., Pavinic, M.J., Homburg, C.H., Ten Cate, J.M. and Graaff, J. (1991) Differences in Cariogenicity between Fresh Isolates of Streptococcus sobrinus and Streptococcus mutans. Caries Research, 25, 116-122. http://dx.doi.org/10.1159/000261353

[33] Russel, R.R.B. and Colman, G. (1981) Immunization of Monkey (Macaca fascicularis) with Purified streptococcus mutans Glucosyltransferase. Archives of Oral Biology, 26, 23-28.

[34] Ayakawa, G.Y., Bleiweis, A.S., Crowley, P.J. and Cunningham, M.W. (1988) Heart Cross-Reactive Antigens of Mutans Streptococci Share Epitopes with Group A Streptococci and Myosin. Journal of Immunology, 140, 253-257.

[35] Canattieri, A.C.V., Kretchetoff, F.Y., Ito, C.I.K., Moreira, D., Fujarra, R.J.C. and Unterkircher, C.S. (2006) Production of Monoclonal Antibodies against Streptococcus mutans Antigens. Brazilian Oral Research, 20, 297-302.

[36] Zhang, P., Jespersgaard, C., Lamberty-Mallorry, L., Katz, J., Huang, Y., Hajishengallis, G. and Michaleki, S.M. (2002) Enhanced Immunogenicity of a Genetic Chimeric Protein Consisting of Two Virulence Antigens of Streptococcus mutans and Protection against Infection. Infection and Immunity, 70, 6779-6787. http://dx.doi.org/10.1128/IAI.70.12.6779-6787.2002

[37] Ajdic, D., Mcshan, W.M., Mclaughlin, R.E., Savic, G., Chang, J., Carson, M.B., Primeaux, C., Tian, R.Y., Kenton, S., Jia, H.G., Lin, S.P., Qian, Y.D., Li, S.L., Zhu, H., Najar, F., Lai, H.S., White, J., Roe, B.A. and Ferretti, J.J. (2002) Genome Sequence of Streptococcus mutans UA159, a Cariogenic Dental Pathogen. Proceedings of the National Academy of Sciences of the United States of America, 99, 14434-14439. http://dx.doi.org/10.1073/pnas.172501299

[38] Smith, D.J., King, W.F., Rivero, J. and Taubman, M.A. (2005) Immunological and Protection Effects Diepitopic Subunit Dental Caries Vaccines. Infection and Immunity, 73, 2797-2804.

[39] Waterhouse, J.C. and Roy, R.B. (2006) Dispensable Genes and Foreign DNA in Streptococcus mutans. Microbiology, 152, 1777-1788. http://dx.doi.org/10.1099/mic.0.28647-0

[40] Hoshino, T., Kondo, Y., Saito, K., Terao, Y., Okahashi, N., Kawabata, S. and Fujiwara, T. (2011) Novel Epitopic Region of Glucosyltransferase B from Streptococcus mutans. Clinical and Vaccine Immunology, 18, 1552-1561. http://dx.doi.org/10.1128/CVI.05041-11

[41] Liu, C., Fan, M., Xu, Q.A. and Li, Y.H. (2008) Biodistribution and Expression of Targeted Fusion Anti-Caries DNA Vaccine pGJA-P/VAX in Mice. Journal of Gene Medicine, 10, 298-305. http://dx.doi.org/10.1002/jgm.1138

[42] Jia, R., Guo, J.H., Fan, M.W., Bian, Z., Fan, B., Yu, F. and Xu, Q.A. (2006) Immunogenicity of CTLA4 Fusion AntiCaries DNA Vaccine in Rabbits and Monkeys. Vaccine, 24, 5192-5200. http://dx.doi.org/10.1016/j.vaccine.2006.03.090

[43] Fan, M.W., Bian, Z., Peng, Z.X., Zhong, Y., Chen, Z., Peng, B. and Jia, R. (2002) A DNA Vaccine Encoding a Cell-Surface Protein Antigen of Streptococcus mutans Protects Gnotobiotic Rats from Caries. Journal of Dental Research, 81, 784-787. http://dx.doi.org/10.1177/154405910208101112

[44] Niu, Y., Sun, J., Fan, M., Xu, Q.A., Guo, J., Jia, R. and Li, Y. (2009) Construction of a New Fusion Anti-Caries DNA Vaccine. Journal of Dental Research, 88, 455-460. http://dx.doi.org/10.1177/0022034509336727

[45] Chen, L., Zhu, J., Li, Y., Lu, J., Gao, L., Xu, H., Fan, M. and Yang, X.L. (2013) Enhanced Nasal Mucosal Delivery and Immunogenicity of Anti-Caries DNA Vaccine through Incorporation of Anionic Liposomes in Chitosan/DNA Complexes. PLOS ONE, 8, e71953. www.plosone.org http://dx.doi.org/10.1371/journal.pone.0071953

[46] Su, L.K., Yu, F., Li, Z., Zeng, C., Xu, Q.A. and Fan, M.W. (2014) Intranasal Co-Delivery of IL-6 Gene Enhances the Immunogenicity of Anti-Caries DNA Vaccine. Acta Pharmacologica Sinica, 35, 592-598. http://dx.doi.org/10.1038/aps.2013.184

[47] Kelly, C.G., Younson, J.S., Hikmat, B.Y., Todryk, S.M., Czisch, M., Haris, P.I., et al. (1999) A Synthetic Peptide Adhesion Epitope as a Novel Antimicrobial Agent. Nature Biotechnology, 17, 42-47. http://dx.doi.org/10.1038/5213

[48] Younson, J. and Kelly, C.G. (2004) The Rational Design of an Anti-Caries Peptide against Streptococcus mutans. Molecular Diversity, 8, 121-126. http://dx.doi.org/10.1023/B:MODI.0000025655.93643.fa 
[49] Jakubovics, N.S., Stromberg, N., Van Dolleweerd, C.J., Kelly, C.G. and Jenkinson, H.F. (2005) Differential Binding Specificities of Oral Streptococcal Antigen I/II Family Adhesins for Human or Bacterial Ligands. Molecular Microbiology, 55, 1591-1605. http://dx.doi.org/10.1111/j.1365-2958.2005.04495.x

[50] Smith, D.J. (2010) Dental Caries Vaccines: Prospects and Concerns. Expert Review of Vaccines, 9, 1-3. http://dx.doi.org/10.1586/erv.09.143 
Scientific Research Publishing (SCIRP) is one of the largest Open Access journal publishers. It is currently publishing more than 200 open access, online, peer-reviewed journals covering a wide range of academic disciplines. SCIRP serves the worldwide academic communities and contributes to the progress and application of science with its publication.

Other selected journals from SCIRP are listed as below. Submit your manuscript to us via either submit@scirp.org or Online Submission Portal.
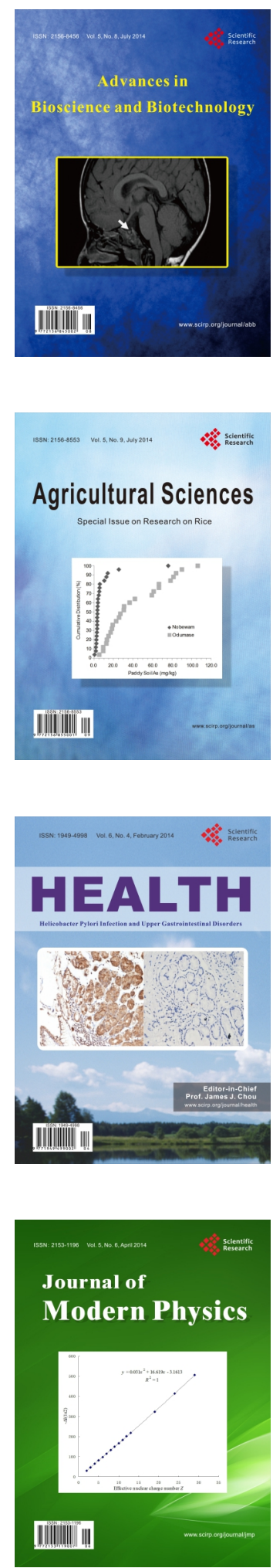
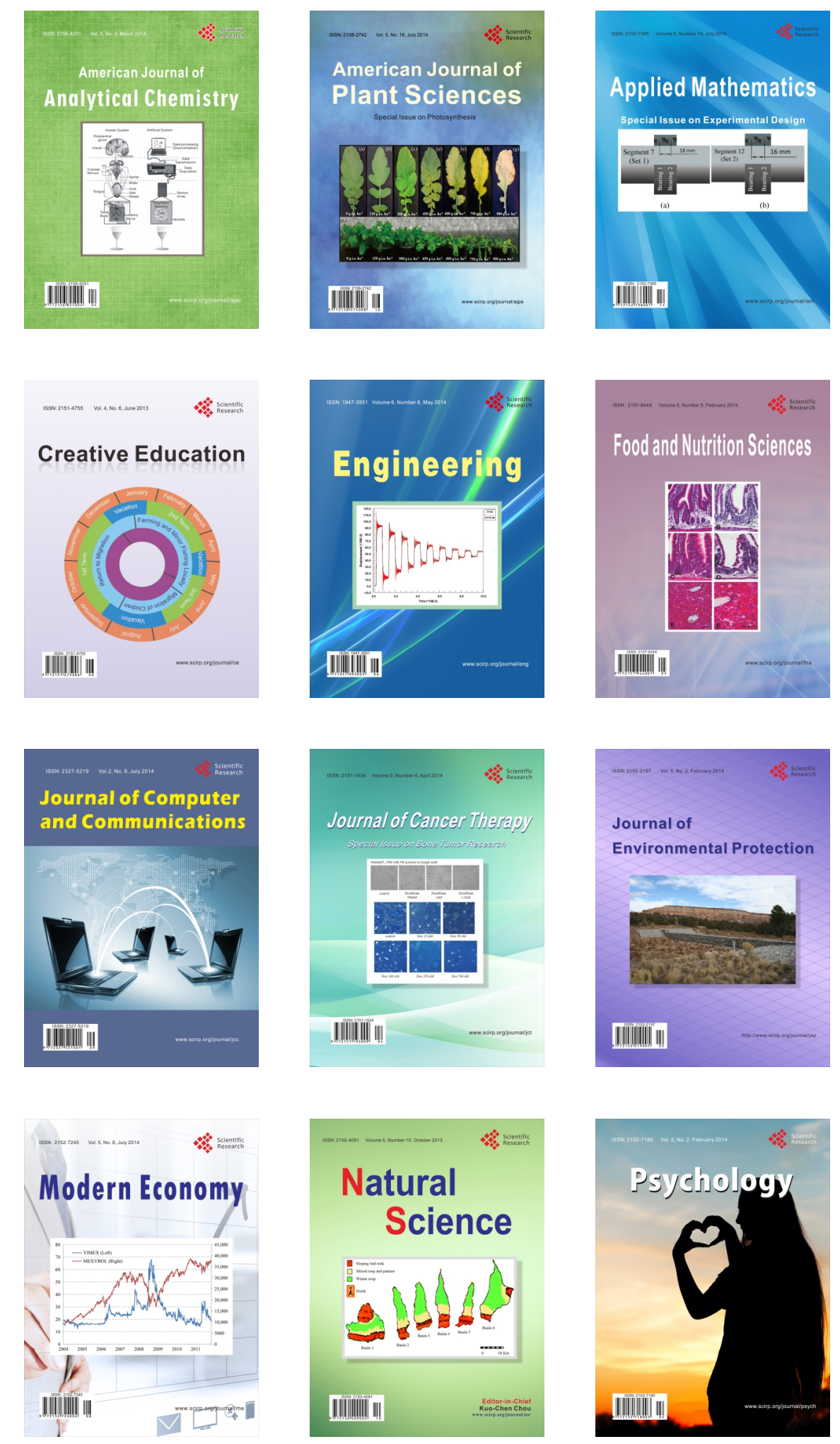